Chapter 12

\title{
Liquefaction of Wood by Ionic Liquid Treatment
}

\author{
Hisashi Miyafuji \\ Additional information is available at the end of the chapter \\ http://dx.doi.org/10.5772/51798
}

\section{Introduction}

Energy and environmental issues such as the exhaustion of fossil resources and global warming are major concerns. There is increasing interest in biomass resources as alternatives to fossil resources owing to their renewable and environmentally friendly properties. Among the various types of biomass, wood is a promising resource, because of its huge stocks and because it is not an edible crop. However, effective conversion technologies are required to use wood for the production of bioenergy or bio-based products. There have been many studies on various conversion technologies, including acid hydrolysis [1-3], enzymatic saccharification [4-5], hot-compressed water treatment [6], supercritical fluid treatment [7-9] and pyrolysis [10-12].

Recently, treatment of wood with ionic liquids has been reported as one of the most promising new conversion technologies for biomass. Ionic liquids are organic salts that have melting points close to ambient temperature. These liquids have many notable characteristics, such as negligible vapor pressure, thermal stability, recyclability, and non-flammability. Some ionic liquids can dissolve cellulose [13-22], and there have been several reports on applications of ionic liquids to liquefy wood [23-30].

In this chapter, recent progress on the liquefaction of wood in an ionic liquid, 1ethyl-3-methylimidazolium chloride ([C2mim][Cl]), which has a chemical structure as shown in Figure 1, is presented. [C2mim][Cl] is well known as an ionic liquid that can dissolve cellulose. The difference in reactivity of lignin and polysaccharides, such as cellulose and hemicellulose, is described. Swelling behavior and the distortion of cell walls during the liquefaction of wood by $[\mathrm{C} 2 \mathrm{mim}][\mathrm{Cl}]$ is also considered. Additionally, the liquefaction of cellulose in $[\mathrm{C} 2 \mathrm{mim}][\mathrm{Cl}]$ with sulfuric acid is presented. 


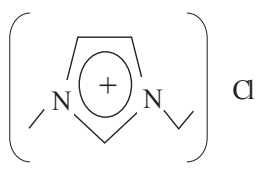

Figure 1. Chemical structure of 1-ethyl-3-methylimidazolium chloride ([C2mim][Cl])

\section{Liquefaction behavior of wood}

\subsection{Changes in chemical components}

Reaction of Japanese beech (Fagus crenata) in [C2mim][Cl] was investigated. Figure 2 shows the changes in residual weight of Japanese beech after $[\mathrm{C} 2 \mathrm{mim}][\mathrm{Cl}]$ treatment at various temperatures. Although $85 \%$ of the residue remains after $24 \mathrm{~h}$ treatment at $90{ }^{\circ} \mathrm{C}$, little residue is recovered after $24 \mathrm{~h}$ treatment at $120^{\circ} \mathrm{C}$. These results indicate that a significant amount of the components of wood can be liquefied in [C2mim][Cl] with higher temperatures and longer treatment times.

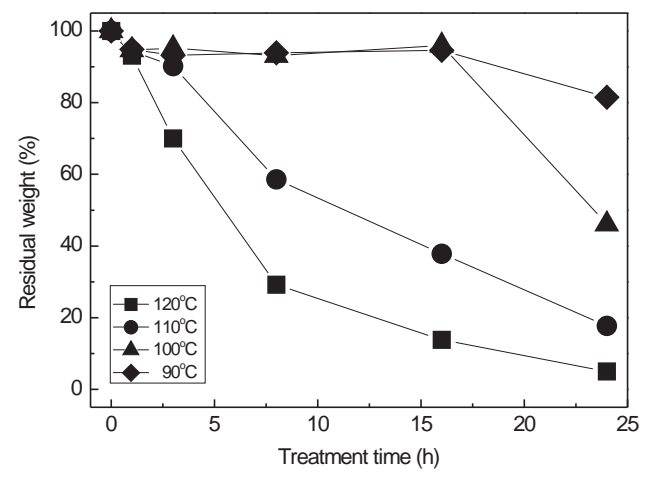

Figure 2. Changes in residual weight of Japanese beech after $[\mathrm{C} 2 \mathrm{mim}][\mathrm{Cl}]$ treatment at various temperatures

Figure 3 shows the changes in the chemical composition of cellulose, hemicellulose and lignin in the residue of western red cedar (Thuja plicata) as softwood and Japanese beech as hardwood treated with $[\mathrm{C} 2 \mathrm{mim}][\mathrm{Cl}]$ at $120^{\circ} \mathrm{C}$. The residue after $8 \mathrm{~h}$ treatment can be reduced to $30 \%$ of western red cedar and $35 \%$ of Japanese beech. In both species, the reduction of lignin was small. Therefore, the decrease of residue until $8 \mathrm{~h}$ was caused mainly by the decrease in the cellulose and hemicellulose in wood. These results indicate that although both lignin and polysaccharides such as cellulose and hemicelluloses can be liquefied, the liquefaction of the latter occurs mainly at the beginning of the reaction with $[\mathrm{C} 2 \mathrm{mim}][\mathrm{Cl}]$. 
Japanese beech was found to be liquefied at a slightly faster rate than western red cedar up to $8 \mathrm{~h}$. However, a significant difference between them was observed at $24 \mathrm{~h}$. While western red cedar remains at a $17 \%$ level, Japanese beech remains at only $5 \%$.

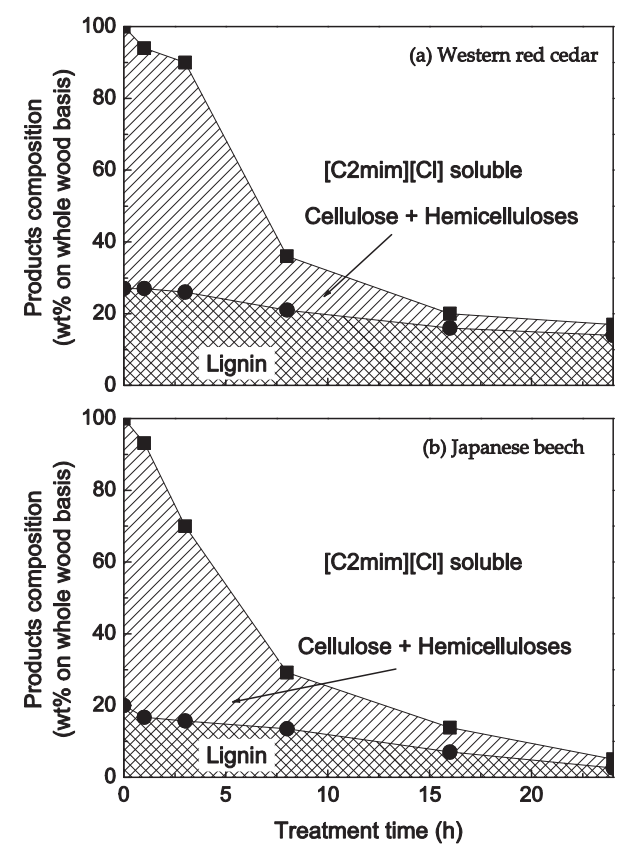

Figure 3. Changes in the chemical composition of cellulose, hemicellulose and lignin in the residue of (a) western red cedar and (b) Japanese beech treated with [C2mim] [Cl] at $120^{\circ} \mathrm{C}$

For more detailed analysis of the changes in chemical components, Figure 4 shows the changes in the percentages of polysaccharide (cellulose and hemicellulose) and lignin following treatment by $[\mathrm{C} 2 \mathrm{mim}][\mathrm{Cl}]$. Each plot was calculated as a percentage of the original amount of each component. The similar trend in the decrease of polysaccharide can be seen in both species. However, lignin in Japanese beech was removed much faster than that in western red cedar. After $24 \mathrm{~h}$ treatment, lignin decreases to $13 \%$ in the former and $52 \%$ in the latter. These results indicate that the reactivity of lignin to [C2mim][Cl] is very different between Japanese beech and western red cedar, and this is due to the difference in the chemical structure of between Japanese beech and western red cedar [27].

The solubilized compounds in $[\mathrm{C} 2 \mathrm{mim}][\mathrm{Cl}]$ during the liquefaction of wood were analyzed by gel permeation chromatography (GPC). Figure 5 shows the GPC chromatograms obtained at various treatment times. Analyses were conducted using a refractive index detector (RID), which can detect all solubilized compounds, and a photodiode array detector (PDA), which can detect those solubilized compounds that exhibit UV absorption. Pullulan was used as a standard for the molecular weight (MW) distribution. At $0 \mathrm{~h}$ in RID, both spe- 
cies have broad peaks with a MW around a few hundred thousand. However, neither of the two species have any peaks at $0 \mathrm{~h}$ in PDA. These results indicate that wood components solubilized in $[\mathrm{C} 2 \mathrm{mim}][\mathrm{Cl}]$ are not lignin but cellulose and hemicellulose at the early stages of reaction. They decrease to MW values of a few tens of thousands after $3 \mathrm{~h}$ in RID. After 8 $\mathrm{h}$ and $24 \mathrm{~h}$, the peaks around $180 \mathrm{MW}$ appear, indicating that the depolymerization of cellulose and hemicellulose occurred in $[\mathrm{C} 2 \mathrm{mim}][\mathrm{Cl}]$ as the treatment was extended. A peak observed at around $180 \mathrm{MW}$ in RID is equivalent to that of a hexose such as glucose, mannose and galactose, which are components of cellulose and hemicellulose. Moreover, the low molecular compounds observed below $180 \mathrm{MW}$ in the PDA chromatograms could possibly include the lignin derived compounds. No significant differences in this depolymerization behavior were found between western red cedar and Japanese beech.

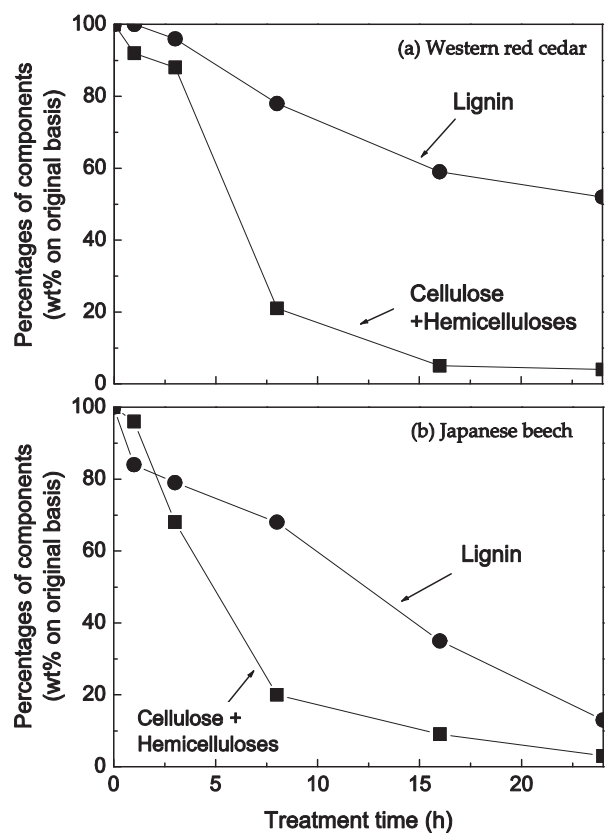

Figure 4. Changes in the percentages of cellulose, hemicellulose and lignin as treated by [C2mim][Cl], based on the original amounts present

In order to identify the low molecular compounds that were found by GPC analysis, gas chromatography coupled with mass spectrometry (GC-MS) analysis was carried out as shown in Figure 5. Products were identified by comparing the retention times and mass fragmentation patterns of the samples to those of pure compounds. The chromatograms of both species show few peaks at $0 \mathrm{~h}, 1 \mathrm{~h}$ and $3 \mathrm{~h}$. However, various major monosugars such as glucose, arabinose, xylose, mannose and galactose are confirmed to be produced after $8 \mathrm{~h}$ and $24 \mathrm{~h}$ treatment. This is strong evidence that the polysaccharides are hydrolyzed to monosugars by the $[\mathrm{C} 2 \mathrm{mim}][\mathrm{Cl}]$ treatment. 

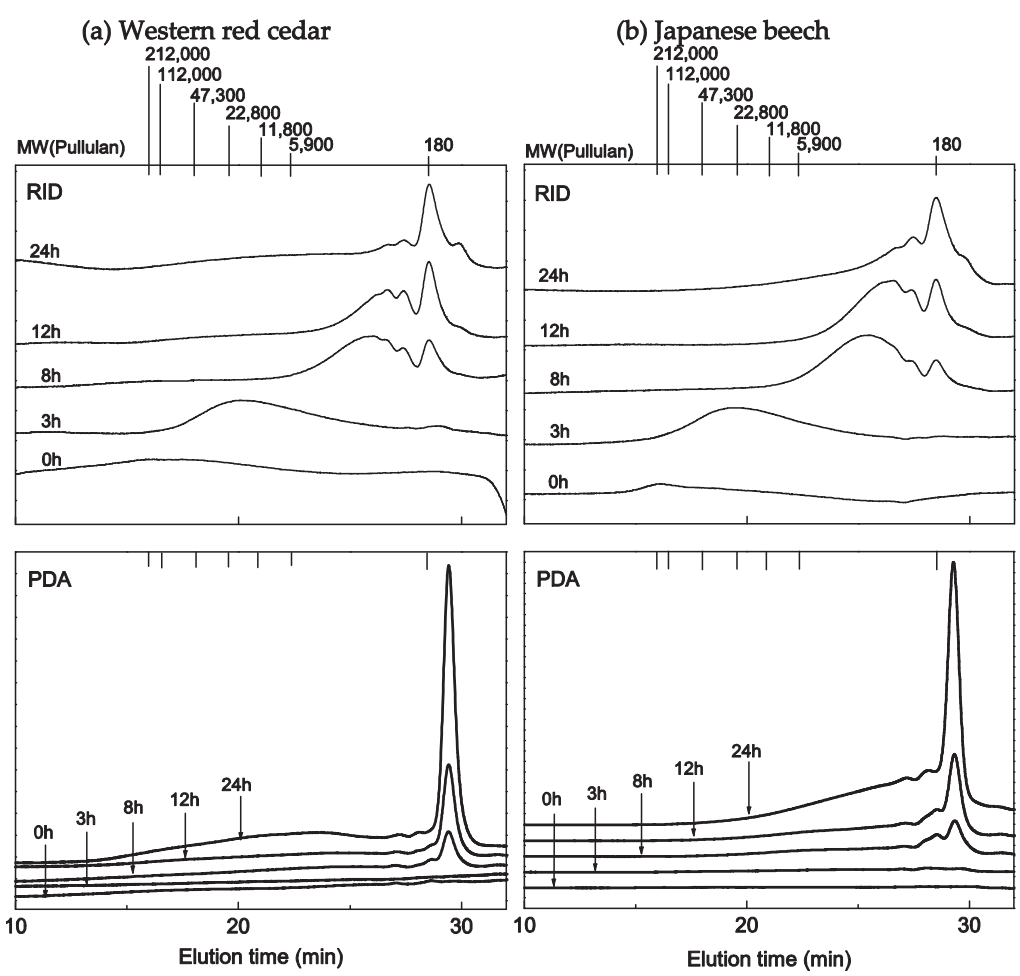

Figure 5. GPC chromatograms for the solubilized compounds in [C2mim] [Cl] from (a) western red cedar and (b) Japanese beech

(a) Western red cedar

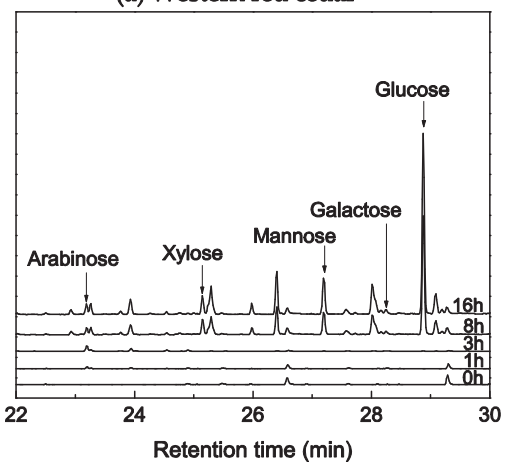

(b) Japanese beech

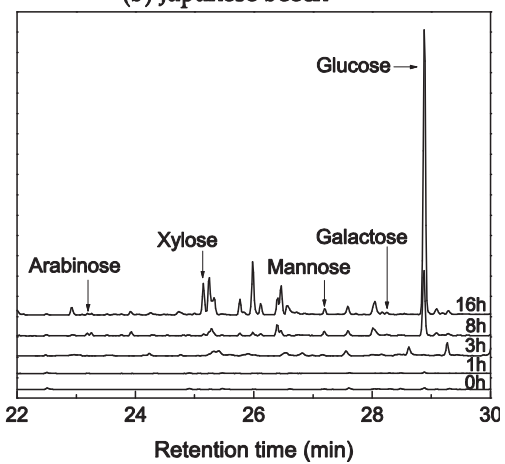

Figure 6. GC-MS chromatograms of the solubilized compounds in [C2mim] [Cl] from (a) western red cedar and (b) Japanese beech 


\subsection{Morphological changes in wood tissue}

The liquefaction behavior of wood in [C2mim][Cl] was studied not only from the changes of chemical components but also from morphological changes taking place in the wood tissues. Figure 7 shows light microscopy images of sugi (Cryptomeria japonica) after treatment with [C2mim] $[\mathrm{Cl}]$ at $120^{\circ} \mathrm{C}$ for $0 \mathrm{~h}$ and $24 \mathrm{~h}$. In the transverse sections, we observed that cell walls in latewood were well ordered at $0 \mathrm{~h}$ (Figure 7a) but disordered and distorted after $24 \mathrm{~h}$ of treatment (Figure 7b). In contrast, no significant morphological changes were seen in earlywood. Although the cell walls in earlywood swelled as a result of [C2mim] $[\mathrm{Cl}]$ treatment, the cells retained a similar form to that seen before treatment. At the boundary regions of latewood and earlywood in the radial sections, dissociation of tracheids was found after $24 \mathrm{~h}$ treatment (Figure $7 \mathrm{~d}$ ).

To analyze in detail the dissociations and distortions in latewood resulting from [C2mim] $[\mathrm{Cl}]$ treatment, the swelling behavior of cell walls in latewood and earlywood in transverse sections was studied.

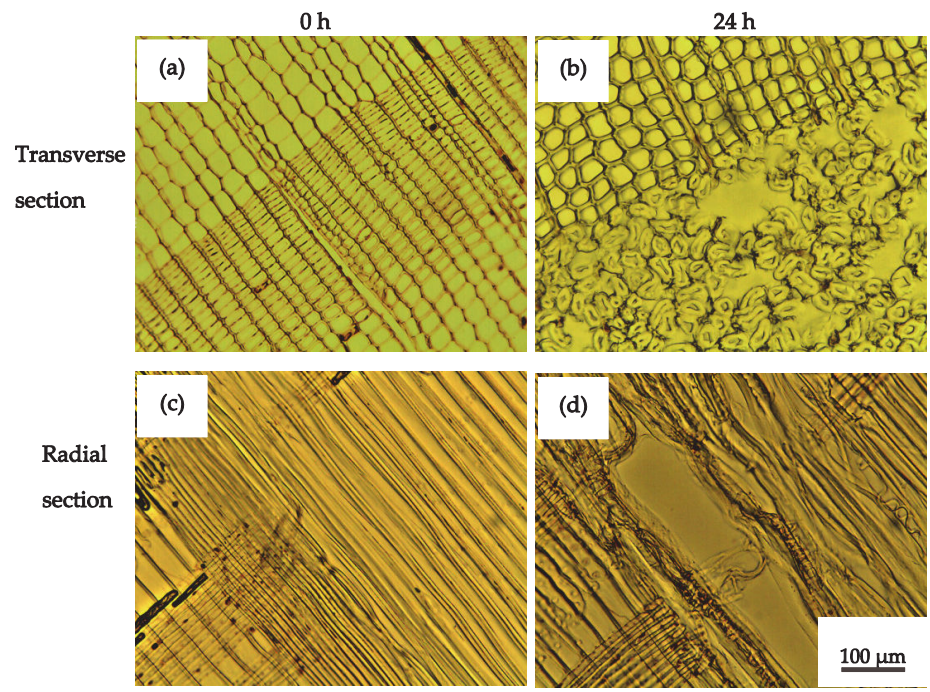

Figure 7. Light microscopy images of transverse sections $(a, b)$ and radial sections $(c, d)$ after treatment with [C2mim] $[\mathrm{Cl}]$ at $120^{\circ} \mathrm{C}$ for $24 \mathrm{~h}$

The results are shown in Figure 8. In earlywood, the cell wall area increased slightly at an early stage of $[\mathrm{C} 2 \mathrm{mim}][\mathrm{Cl}]$ treatment. After these initial changes in cell wall area, the cell wall area remained stable and did not show further changes during the $[\mathrm{C} 2 \mathrm{mim}][\mathrm{Cl}]$ treatment. These results indicate that cell walls of tracheids in earlywood did not swell significantly. In latewood, on the other hand, there were marked increases in the cell wall area at an early stage of $[\mathrm{C} 2 \mathrm{mim}][\mathrm{Cl}]$ treatment. At $48 \mathrm{~h}$ of treatment, the cell wall area had increased by five times. This swelling is likely to have caused the dissociation and distortions in latewood. Once the tracheids have dissociated, their cell walls can swell freely because 
there are no longer the physical restraints of neighboring cell walls. These results indicate differences in the morphological changes between earlywood and latewood (Figure 7)

Figure 9 shows scanning electron microscopy (SEM) images of transverse sections after treatment by $[\mathrm{C} 2 \mathrm{mim}][\mathrm{Cl}]$ for $24 \mathrm{~h}$. The dissociation and distortions of cell walls are found in latewood after $24 \mathrm{~h}$ treatment (Figure $9 \mathrm{~b}$ ) as observed in the light micrograph images in Figure 8. Magnified SEM image (Figure 9d) reveals the dissociation between the secondary cell wall and the intercellular layer (indicated by arrows). [C2mim] $[\mathrm{Cl}]$ is known to liquefy cellulose and hemicelluloses much more than lignin as shown in Figure 3. Thus, the reaction behavior of secondary cell walls and the intercellular layer is thought to be different from each other because the chemical components in those tissues are different. It is speculated that such differences in reaction behavior cause differences in their swelling behavior, and dissociation between secondary cell walls and the intercellular layer occurs.

Figure 10 shows SEM images of radial sections after treatment by [C2mim][Cl] for $24 \mathrm{~h}$. The dissociation of tracheids with flaking and distortion in latewood is found (Figure $10 \mathrm{~b}$ ). The magnified image (Figure 10d) shows that the ray tracheids are segmented and the segments can be clearly observed on the tracheids (indicated by arrows). These results indicate that swelling of the tracheids in the radial direction is much greater than that in the axial direction.

Figure 11 shows SEM images of bordered pit-pair at earlywood in tangential sections. At $0 \mathrm{~h}$ treatment (Figure 11a), a torus is found in bordered pit-pair as shown by the arrow. However, it disappears after $48 \mathrm{~h}$ treatment (Figure 11b) while bordered pit-pair can be observed without any morphological changes. As shown in Figs. 7, 9 and 10, significant morphological changes were not found in tracheids in earlywood. Pit membrane is built up mainly by accumulation of cellulose microfibrils [31]. In the previous section, it is mentioned that cellulose is easily liquefied compared with lignin. Thus, many pit membranes are thought to be destroyed by $[\mathrm{C} 2 \mathrm{mim}][\mathrm{Cl}]$ treatment.

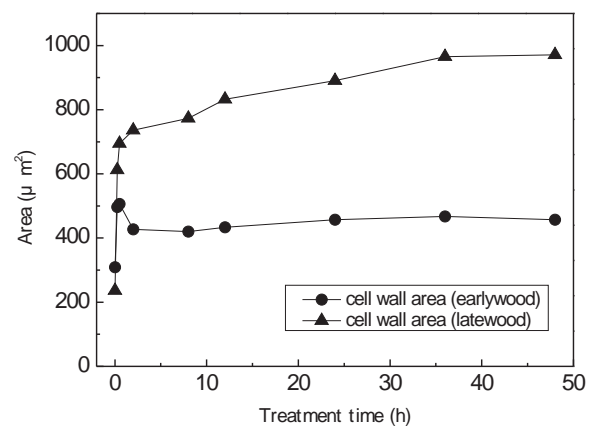

Figure 8. Changes of cell wall area in earlywood and latewood during $[\mathrm{C} 2 \mathrm{mim}][\mathrm{Cl}]$ treatment at $120^{\circ} \mathrm{C}$ 
Consequently, these results indicate that $[\mathrm{C} 2 \mathrm{mim}][\mathrm{Cl}]$ is an effective solvent and reagent for the liquefaction of wood components and subsequent depolymerization of them. However, the reaction of wood liquefaction by $[\mathrm{C} 2 \mathrm{mim}][\mathrm{Cl}]$ treatment is not homogeneous, from either chemical or morphological viewpoints.

\subsection{Influence of reaction atmosphere}

The influence of moisture and reaction atmosphere on the liquefaction of wood (western red cedar) was studied. The changes in the residue and the composition after treatment by [C2mim] $[\mathrm{Cl}]$ for $24 \mathrm{~h}$ under various atmospheres are shown in Figure 12. The samples treated under humidified oxygen $\left(\mathrm{O}_{2}+\mathrm{H}_{2} \mathrm{O}\right)$ and oxygen $\left(\mathrm{O}_{2}\right)$ drop to $4 \%$ and $6 \%$ respectively, while those under carbon dioxide $\left(\mathrm{CO}_{2}\right)$, nitrogen $\left(\mathrm{N}_{2}\right)$ and vacuum remain above $35 \%$. The samples treated under humidified pseudo-air (air $+\mathrm{H}_{2} \mathrm{O}$ ) and pseudo-air (air), which contain $21 \%$ oxygen and $79 \%$ nitrogen respectively, drop to $18 \%$ and $19 \%$ respectively. These results indicate that oxygen considerably accelerates the liquefaction of wood in [C2mim] [Cl]. In addition, a few percentage points difference can also be observed between the samples treated under gas and those with moisture. The presence of water slightly affects the liquefaction of wood in [C2mim][Cl].

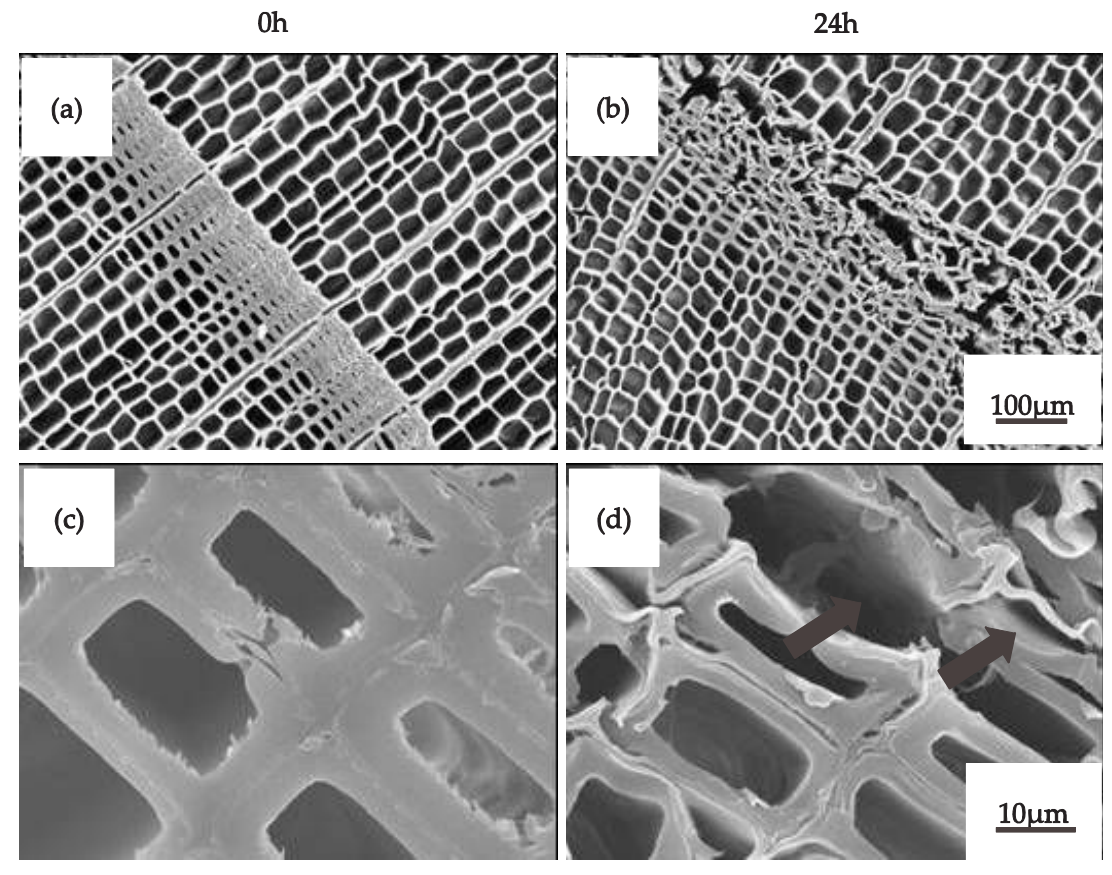

Figure 9. SEM images of transverse sections treated with [C2mim] [Cl] at $120^{\circ} \mathrm{C}$ for $24 \mathrm{~h} .(\mathrm{a}, \mathrm{c}) 0 \mathrm{~h}$ treatment, $(\mathrm{b}, \mathrm{d}) 24 \mathrm{~h}$ treatment. 


\section{$\stackrel{\text { Earlywood }}{\longleftrightarrow} \stackrel{\text { Latewood }}{\longleftrightarrow}$}
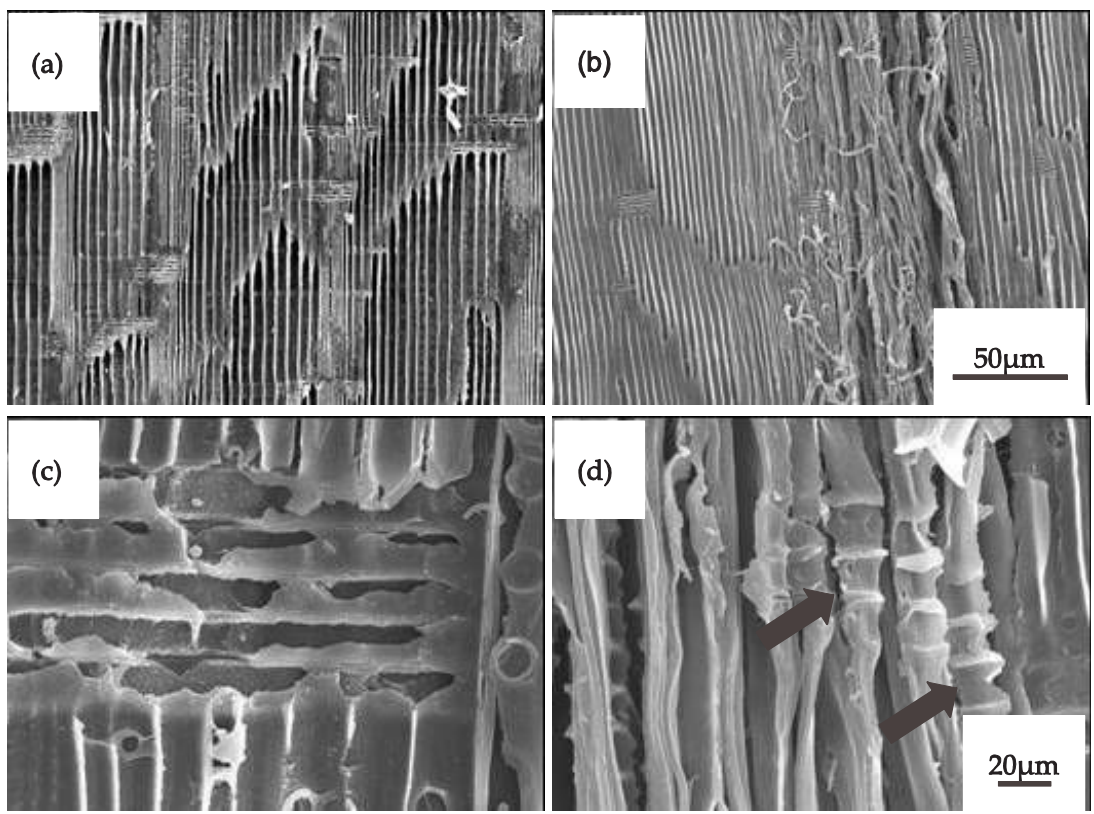

Figure 10. SEM images of radial sections after treatment with $[\mathrm{C} 2 \mathrm{mim}][\mathrm{Cl}]$ at $120^{\circ} \mathrm{C}$ for $24 \mathrm{~h} .(\mathrm{a}, \mathrm{c}) 0 \mathrm{~h}$ treatment, $(\mathrm{b}, \mathrm{d})$ $24 \mathrm{~h}$ treatment.
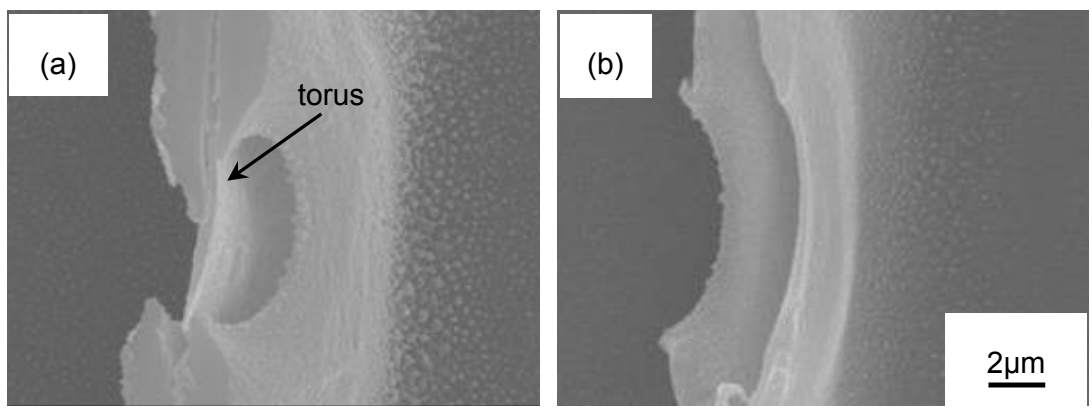

Figure 11. SEM images of bordered pit-pair in earlywood in tangential sections after treatment by $[\mathrm{C} 2 \mathrm{mim}][\mathrm{Cl}]$ at 120 ${ }^{\circ} \mathrm{C}$ for $0 \mathrm{~h} \mathrm{(a)}$ and $48 \mathrm{~h}(\mathrm{~b})$

For further investigation of low molecular compounds solubilized in [C2mim][Cl], high performance liquid chromatography analysis was carried out as shown in Figure 13. Both sam- 
ples treated under $\mathrm{Air}+\mathrm{H}_{2} \mathrm{O}$ and Air show peaks at around $10.5 \mathrm{~min}$ and $12.5 \mathrm{~min}$ in retention time, which are cellobiose and glucose, respectively. The complex peaks observed between $7.5 \mathrm{~min}$ and $9.5 \mathrm{~min}$ in retention time are thought to be oligomers. The samples treated under inactive gases are degraded to oligomers and those treated under $\mathrm{Air}+\mathrm{H}_{2} \mathrm{O}$ and air are degraded to glucose by the $[\mathrm{C} 2 \mathrm{mim}][\mathrm{Cl}]$ treatment. Under $\mathrm{O}_{2}+\mathrm{H}_{2} \mathrm{O}$ and $\mathrm{O}_{2}$, there are no clear peaks in the chromatograms. This is due to the fact that glucose is quickly degraded to other lower molecular compounds such as 5-hydroxymethylfurfural because of the high activity of $\mathrm{O}_{2}$.

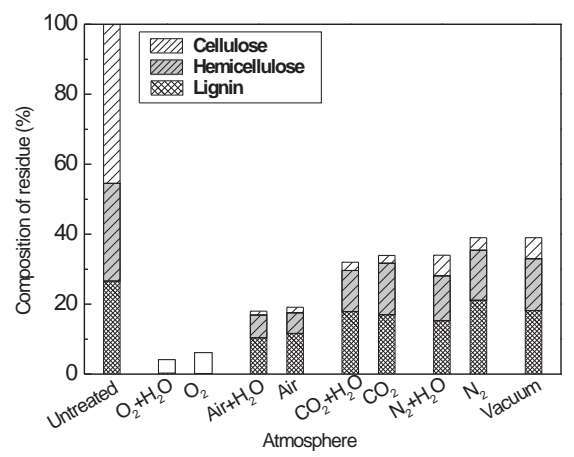

Figure 12. Changes in the residue and composition as treated by [C2mim] [Cl] for $24 \mathrm{~h}$ under various atmospheres

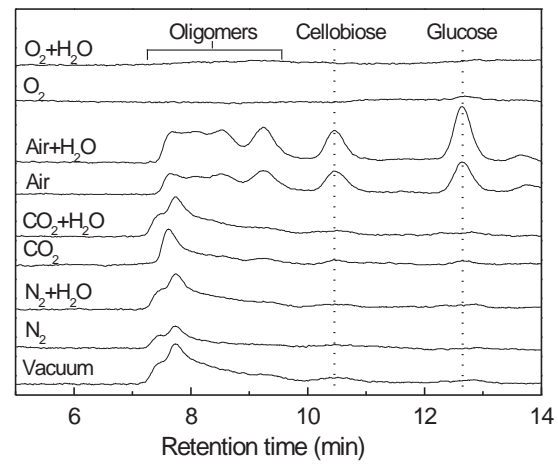

Figure 13. High performance liquid chromatograms of the solubilized compounds in [C2mim][Cl] obtained by $24 \mathrm{~h}$ treatment under various reaction atmospheres

In general, it is shown that active gases such as $\mathrm{O}_{2}$ and air considerably accelerate wood liquefaction in [C2mim] $[\mathrm{Cl}]$, and even with inactive gases such as $\mathrm{N}_{2}$ and $\mathrm{CO}_{2}$, liquefaction proceeds, which means $[\mathrm{C} 2 \mathrm{mim}][\mathrm{Cl}]$ itself has the ability to liquefy wood. 


\section{Liquefaction of cellulose in $[\mathrm{C} 2 \mathrm{mim}][\mathrm{Cl}]$ with sulfuric acid}

In the previous section, it is clear that glucose can be obtained by the liquefaction of wood. This is mainly due to the depolymerization of cellulose. Glucose is one of the most important compounds among various compounds derived from wood because it can be converted to a range of valuable chemicals. For producing glucose, therefore, the liquefaction of cellulose in $[\mathrm{C} 2 \mathrm{mim}][\mathrm{Cl}]$ with sulfuric acid was also studied.

Figure 14 shows the changes in glucose yield at various reaction temperatures. The concentration of sulfuric acid in the reaction system was set at $1.5 \mathrm{wt} \%$. In any reaction temperature except for $90{ }^{\circ} \mathrm{C}$, glucose yield shows the optimum around $30 \%$ to $40 \%$. Although the significant difference in maximal yield at each reaction temperature was not observed, the highest yield was $40.9 \%$ at $90{ }^{\circ} \mathrm{C}$. The maximal yield could be attained at shorter reaction times at increasing reaction temperature.

Figure 15 shows the changes of the glucose yield at various reaction temperatures with $0.5 \mathrm{wt} \%$ of sulfuric acid. Maximal yields were found at $120{ }^{\circ} \mathrm{C}$ and $60 \mathrm{~min}$ and at $110{ }^{\circ} \mathrm{C}$ and $120 \mathrm{~min}$, respectively, although the glucose yield could not reach the optimum yet at $100{ }^{\circ} \mathrm{C}$ or $90{ }^{\circ} \mathrm{C}$, even after $360 \mathrm{~min}$. Compared with the results in $1.5 \mathrm{wt} \%$ of sulfuric acid as shown in Figure 14, a longer reaction time is necessary to attain the maximal yield. However, the maximum value at $120{ }^{\circ} \mathrm{C}$ or $110{ }^{\circ} \mathrm{C}$ shows the same levels as in 1.5 $\mathrm{wt} \%$ of sulfuric acid. These results indicate that the reaction of cellulose in $[\mathrm{C} 2 \mathrm{mim}][\mathrm{Cl}]$ can be controlled by various reaction conditions such as the concentration of sulfuric acid, reaction time and reaction temperature.

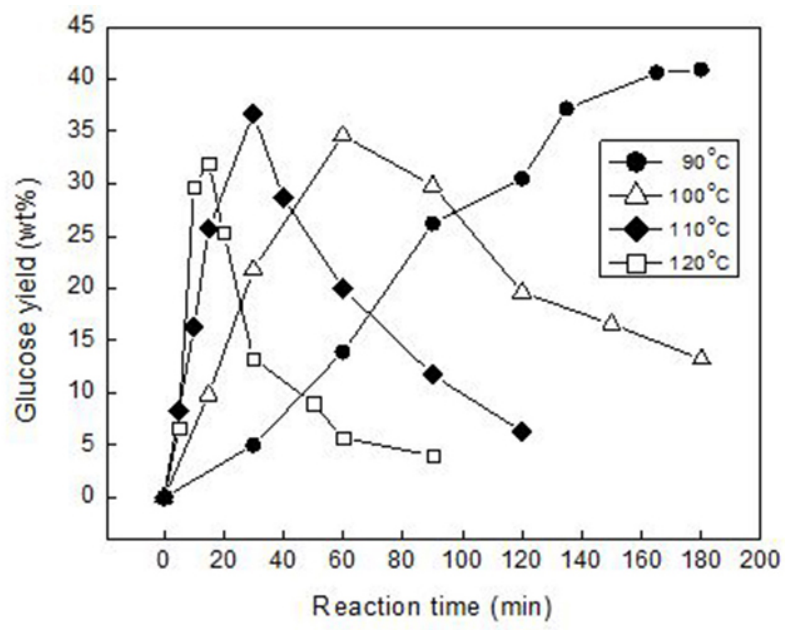

Figure 14. Changes in glucose yield from cellulose treated in $[\mathrm{C} 2 \mathrm{mim}][\mathrm{Cl}]$ with $1.5 \mathrm{wt} \%$ of sulfuric acid at various reaction temperatures. 
Figure 16 shows the comparisons of the glucose yield in the reaction system of [C2mim] $\mathrm{Cl}]$ and water as solvent at $90{ }^{\circ} \mathrm{C}$ (Figure 16a) or $120{ }^{\circ} \mathrm{C}$ (Figure 16b) reaction temperature. Sulfuric acid was added at $1.5 \mathrm{wt} \%$. At both reaction temperatures, it reveals that much higher yields can be achieved in the reaction system of [C2mim][Cl] although they are at a negligible level in the reaction system of water. From these results, glucose productivity was calculated by the equation shown below.

Glucose productivity $=\frac{\text { Maximal glucose yield }(\%)}{\text { Reaction time at maximal glucose yield (min) }}$

The obtained glucose productivity is shown in Table 1 . The reaction system of [C2mim] $\mathrm{Cl}]$ at $90{ }^{\circ} \mathrm{C}$ and $120{ }^{\circ} \mathrm{C}$ showed, respectively, 10 and 100 times the glucose productivity of the reaction system of water at $120^{\circ} \mathrm{C}$. These results indicate that cellulose can be converted to glucose much more effectively in $[\mathrm{C} 2 \mathrm{mim}][\mathrm{Cl}]$ than in water. By dissolving cellulose in $[\mathrm{C} 2 \mathrm{mim}][\mathrm{Cl}]$, the rigid crystalline structure of cellulose can be destroyed. This is a reason for the higher reactivity of cellulose in the reaction system of [C2mim][Cl].

It is revealed that much higher glucose yield can be achieved in the reaction system of $[\mathrm{C} 2 \mathrm{mim}][\mathrm{Cl}]$ around $100{ }^{\circ} \mathrm{C}$, compared with that obtained in water, which cannot dissolve cellulose. Therefore, it can be concluded that the ionic liquid that can dissolve cellulose is a promising solvent for producing glucose.

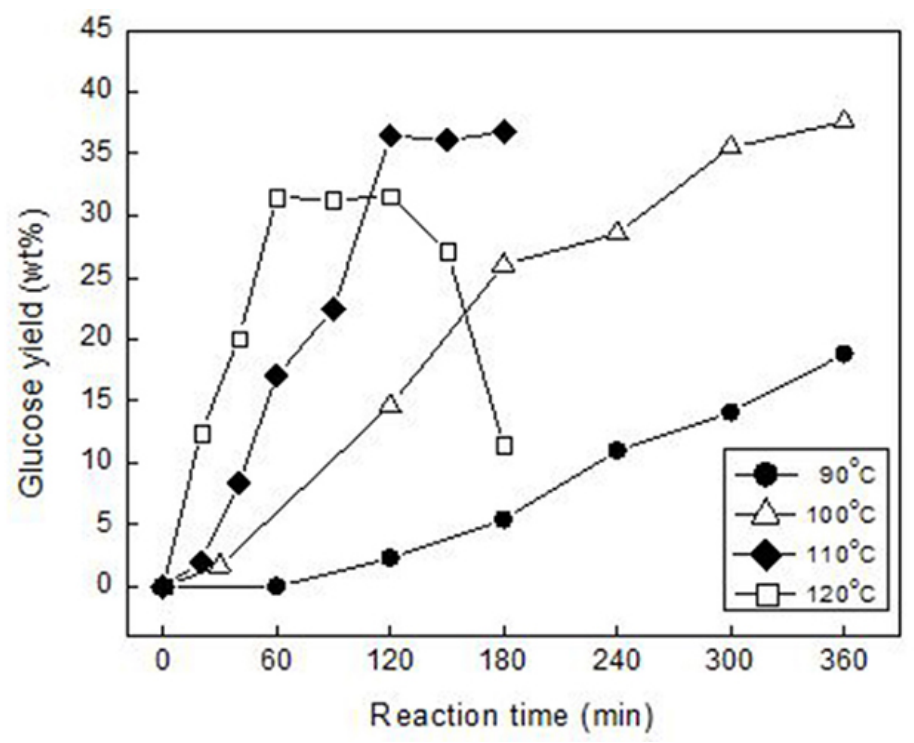

Figure 15. Changes in glucose yield from cellulose treated in $[\mathrm{C} 2 \mathrm{mim}][\mathrm{Cl}]$ with $0.5 \mathrm{wt} \%$ sulfuric acid at various reaction temperatures 
(a) $90^{\circ} \mathrm{C}$

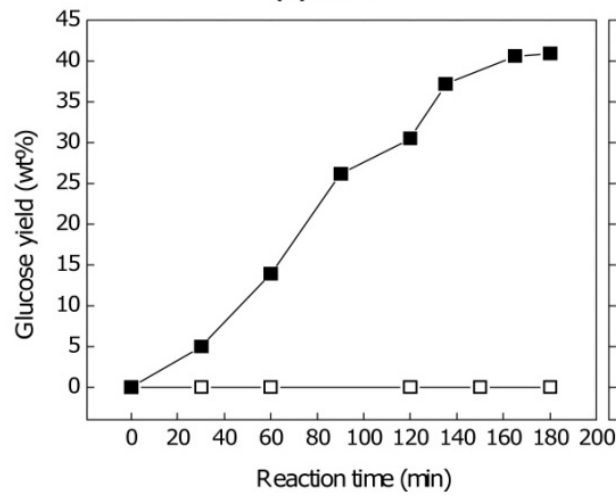

(b) $120^{\circ} \mathrm{C}$

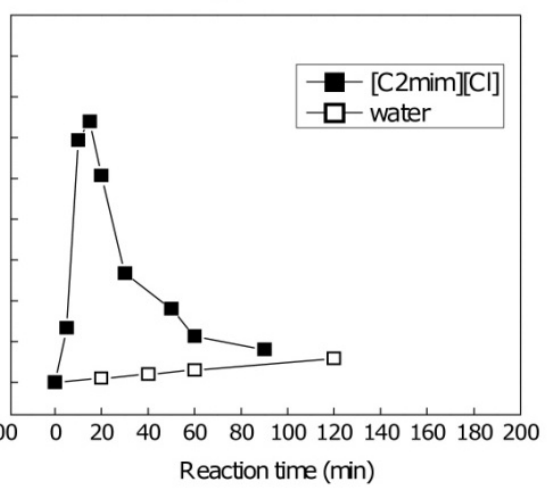

Figure 16. Comparisons of glucose yield from cellulose treated in the reaction system of [C2mim] [Cl] and water as solvent at (a) $90^{\circ} \mathrm{C}$ and (b) $120^{\circ} \mathrm{C}$ with $1.5 \mathrm{wt} \%$ sulfuric acid

\begin{tabular}{ccc}
\hline Reaction system & Reaction temperature $\left({ }^{\circ} \mathrm{C}\right)$ & Glucose productivity* \\
\hline Water & 90 & 0.00 \\
& 120 & 0.02 \\
\hline$[\mathrm{C} 2 \mathrm{mim}][\mathrm{Cl}]$ & 90 & 0.23 \\
& 120 & 2.13 \\
\hline
\end{tabular}

*Glucose productivity = Maximal glucose yield (\%) / Reaction time at maximal glucose yield (min)

Table 1. Glucose productivity from cellulose in water and the $[\mathrm{C} 2 \mathrm{mim}][\mathrm{Cl}]$ reaction system.

\section{Conclusion}

This chapter demonstrated that $[\mathrm{C} 2 \mathrm{mim}][\mathrm{Cl}]$, which can dissolve cellulose, liquefies wood components with the depolymerization of these substances. Cellulose can be effectively converted to glucose in $[\mathrm{C} 2 \mathrm{mim}][\mathrm{Cl}]$ with sulfuric acid. It is concluded from these results that [C2mim][Cl] can work not only as a solvent for wood or cellulose but also as a reagent for converting them to low MW compounds. These findings suggest that $[\mathrm{C} 2 \mathrm{mim}][\mathrm{Cl}]$ is applicable to the chemical conversion of wood or cellulose to useful chemicals. This achievement opens the way for an effective utilization of wood or cellulose.

However, the liquefaction of wood by $[\mathrm{C} 2 \mathrm{mim}][\mathrm{Cl}]$ treatment is not homogeneous, from either a chemical or morphological viewpoint. Additionally, with wood species as raw materials, the reaction atmosphere significantly influences the liquefaction reaction. Thus, further specific research is necessary for industrialization to maximize the target product from wood. 


\section{Acknowledgments}

This work was partly supported by JFE $21^{\text {st }}$ Century Foundation, the Sumitomo Foundation, a Grant-in-Aid for Exploratory Research (20658041) and the TOSTEM Foundation for Construction Materials Industry Promotion for which authors are grateful.

\section{Author details}

Hisashi Miyafuji

Division of Environmental Sciences, Graduate School of Life and Environmental Sciences Kyoto Prefectural University, Kyoto, Japan

\section{References}

[1] Goldstein IS. The hydrolysis of wood. TAPPI 1980;63 141-143.

[2] Kim, J. S., \& Lee, Y. Y. (2000). Fundamental aspects of dilute acid hydrolysis/fractionation kinetics of hardwood carbohydrates. 1. Cellulose hydrolysis. Industrial \& Engineering Chemistry Research 2000;39 2817-2825.

[3] Iranmahboob J, Nadim F, Monemi S. Optimizing acid-hydrolysis: a critical step for production of ethanol from mixed wood chips. Biomass and Bioenergy 2002;22 401-404.

[4] Chang V. S., \& Holzapple, M. T. (2000). Fundamental factors affecting biomass enzymatic reactivity. Applied Biochemistry and Biotechnology 2000;38 53-87.

[5] Ortega N, Busto, M. D., \& Perez-Mateos, M. Kinetics of cellulose saccharification by Trichoderma reesei cellulases. International Biodeterioration \& Biodegradation 2001;47 7-14.

[6] Mok, W. S., \& Antal Jr., M. J. Uncatalyzed solvolysis of whole biomass hemicelluloses by hot compressed liquid water. Industrial \& Engineering Chemistry Research 1992;31 1157-1161.

[7] Saka S, Konishi R. Chemical conversion of biomass resources to useful chemicals and fuels by supercritical water treatment. In: Bridgewater AV (ed) Progress in thermochemical biomass conversion, Blackwell, Oxford; 2001. p1338-1348.

[8] Yamazaki J, Minami E, Saka S. Liquefaction of beech wood in various supercritical alcohols. Journal of Wood Science 2006;52 527-532.

[9] Mishra G, Saka S. Kinetic behavior of liquefaction of Japanese beech subcritical phenol. Bioresource Technology 2011;102 10946-10950. 
[10] Kwon G J, Kuga S, Hori K, Yatagai M, Ando K, Hattori N. Saccharification of cellulose by dry pyrolysis. Journal of Wood Science 2006;52 461-465.

[11] Hosoya T, Kawamoto H, Saka S. Influence of inorganic matter on wood pyrolysis at gasification temperature. Journal of Wood Science 2007;53 351-357.

[12] Asmadi M, Kawamoto H, Saka S. Pyrolysis reaction of Japanese cedar and Japanese beech woods in a closed ampoule reactor. Journal of Wood Science 2010;56 319-330.

[13] Pinkert A, Marsh K N, Pang S, Staiger MP. Ionic liquids and their interaction with cellulose. Chemical Reviews 2009;109 6712-6728.

[14] Moulthrop JS, Swatroski RP, Moyna G, Rogers RD. High-resolution ${ }^{13}$ C NMR studies of cellulose and cellulose oligomers in ionic liquid solutions. Chemical Communications 2005; 2005-1557.

[15] Remsing RC, Swatroski RP, Rogers RD, Moyna G. Mechanism of cellulose dissolution in the ionic liquid 1-n-butyl-3-methylimidazolium chloride: a ${ }^{13} \mathrm{C}$ and ${ }^{35 / 37} \mathrm{Cl}$ NMR relaxation study on model systems. Chemical Communications 2006; 2006-1271.

[16] Remsing RC, Harnandez G, Swatroski RP, Massefski WW, Rogers RD, Moyna G. Solvation of carbohydrates in $\mathrm{N}, \mathrm{N}^{\prime}$-dialkylimidazolium ionic liquids: A multinuclear NMR spectroscopy study. Journal of Physical Chemistry B 2008;112 11071-11078.

[17] Youngs TGA, Holbrey JD, Deetlefts M, Nieuwenhuyzen M, Gomes MFC, Hardacre C. A molecular dynamics study of glucose solvation in the ionic liquid 1,3-dimethylimidazolium chloride. ChemPhysChem 2006, 7-2279.

[18] Youngs TGA, Hardacre C , Holbrey JD. Glucose solvation by the ionic liquid 1,3-dimethylimidazolium chloride: A simulation study. Journal of Physical Chemistry B 2007, 111-13765.

[19] Liu H, Sale KL, Holmes BM, Simmons BA, Singh S. Understanding the interactions of cellulose with ionic liquids: A molecular dynamics study. Journal of Physical Chemistry B 2010;114 4293-4301.

[20] Zhang H, Wu J, Zhang J, He J. 1-Allyl-3-methylimidazolium chloride room temperature ionic liquid: A new and powerful nonderivatizing solvent for cellulose. Macromolecules 2005, 38-8272.

[21] Fukaya Y, Hayashi K, Wada M, Ohno H. Cellulose dissolution with polar ionic liquids under mild conditions: required factors for anions. Green Chemistry 2008;10 44-46.

[22] Nakamura A, Miyafuji H, Saka S, Mori M, Takahashi H. (2010) Recovery of cellulose and xylan liquefied in ionic liquids by precipitation in anti-solvents. Holzforschung 2010;64 77-79.

[23] Xie H, Shi T. Wood liquefaction by ionic liquid. Holzforschung 2006;60 509-512. 
[24] Kilpeläinen I, Xie H, King A, Granstrom M, Heikkinen S, Argyropoulos DS. Dissolution of wood in ionic liquids. Journal of Agricultural and Food Chemistry 2007;55 9142-9148.

[25] $\mathrm{Pu} \mathrm{Y,} \mathrm{Jiang} \mathrm{N,} \mathrm{Ragauskas} \mathrm{AJ.} \mathrm{Ionic} \mathrm{liquid} \mathrm{as} \mathrm{a} \mathrm{green} \mathrm{solvent} \mathrm{for} \mathrm{lignin.} \mathrm{Journal} \mathrm{of}$ Wood Chemistry and Technology 2007;27 23-33.

[26] Miyafuji H, Miyata K, Saka S, Ueda F, Mori M. (2009) Reaction behavior of wood in an ionic liquid, 1-ethyl-3-methylimidazolium chloride. Journal of Wood Science 2009;55 215-219.

[27] Nakamura A, Miyafuji H, Saka S. Liquefaction behaviour of Western red cedar and Japanese beech in the ionic liquid 1-ethyl-3-methylimidazolium chloride. Holzforschung 2010, 64-289.

[28] Nakamura A, Miyafuji H, Saka S. Influence of reaction atmosphere on the liquefaction and depolymerisation of wood in an ionic liquid, 1-ethyl-3-methylimidazolium chloride. Journal of Wood Science 2010, 56-256.

[29] Miyafuji H, Suzuki N. Observation by light microscope of sugi (Cryptomeria japonica) treated with the ionic liquid, 1-ethyl-3-methylimidazolium chloride. Journal of Wood Science 2011, 57-459.

[30] Miyafuji H, Suzuki N. Morphological changes in sugi (Cryptomeria japonica) wood after treatment with the ionic liquid, 1-ethyl-3-methylimidazolium chloride, Journal of Wood Science 2012, 58-222.

[31] Tsoumis G. Chemical composition and ultrastructure of wood. In: Tsoumis G (ed) Science and technology of Wood. Van Nostrand Reinhold, New York; 1991. p42-46. 